\title{
Pengaruh Proses Degumming Menggunakan Asam Sitrat Terhadap Kualitas Minyak Buah Merah (Pandanus conoideus Lamk)
}

\section{The effect of degumming process using citric acid on the quality of red fruit oil (Pandanus conoideus Lamk.)}

\author{
Abidin Pratama Mayalibit ${ }^{1}$, Zita Letviany Sarungallo $^{1 *}$, Sritina N. P. Paiki ${ }^{1}$ \\ ${ }^{1}$ Prodi Teknologi Hasil Pertanian, Fakultas Teknologi Pertanian, Universitas Papua. Jl. Gunung Salju, \\ Amban,Manokwari-98314, Papua Barat \\ *Email: zlsarungallo@yahoo.com
}

\begin{abstract}
The oil of red fruit extract (Pandanus conoideus L.) is generally still contain impurities. Therefore, it needs to be degumming to remove gum and other impurities. The purpose of this research was to determine the influence of degumming process using citric acid to the quality of red fruit oil. Degumming treatment using citric acid with a concentration of $0.2 \%, 0.5 \%$ and $1 \%$, were compared to the control (red fruit oil without degumming). Analysis of degummed red fruit oil included moisture content, free fatty acids (FFA), peroxide numbers, phosphorus content, total carotenoids and tocopherol. The results of this study showed that the process of degumming using citric acid at a concentration of 0.2-1\% produced red fruit oil with water content (0,053-0,094\%), free fatty acids (FFA) (1,025-1,095\%), peroxide numbers (0,291-0,592 $\mathrm{mg}$ O2/100mg), and also could decrese phosphor levels to $84,272-62,806 \mathrm{mg} / \mathrm{kg}$ in range, with a total carotenoid level of $5831-6786 \mathrm{mg} / \mathrm{kg}$ and a total tocopherol of 2081-2399 $\mathrm{mg} / \mathrm{kg}$. The effective degumming process to reduce phosphorus levels of crude red fruit oil is in the treatment with a concentration of citric acid of $1 \%$. .
\end{abstract}

Keywords: red fruit (Pandanus conoideus L.), degumming, citric acid, oil quality.

\begin{abstract}
Abstrak
Minyak hasil ekstrak buah merah (Pandanus conoideus L.) umumnya masih mengandung komponen pengotor, sehingga perlu di-degumming untuk menghilangkan gum dan komponen pengotor lainnya. Tujuan penelitian ini adalah menentukan pengaruh proses degumming menggunakan asam sitrat terhadap kualitas minyak buah merah. Perlakuan degumming menggunakan asam sitrat dengan konsentrasi beberapa konsentrasi yaitu $0,2 \%, 0,5 \%$ dan $1 \%$ yang dibandingkan dengan kontrol (minyak buah merah tanpa degumming). Analisis kualitas minyak buah merah hasil degumming meliputi kadar air, asam lemak bebas (ALB), bilangan peroksida (BP), kadar fosfor, total tokoferol, dan total karoten minyak buah merah. Hasil penelitian ini menunjukkan bahwa hasil penelitian ini menunjukkan bahwa proses degumming menggunakan asam sitrat pada konsentrasi 0,2-1\% menghasilkan minyak buah merah dengan kadar air $(0,053-0,094 \%)$, asam lemak bebas (ALB) $(1,025-$ $1,095 \%)$, bilangan peroksida $(0,291-0,592 \mathrm{mg} \mathrm{O} / 100 \mathrm{mg})$, dan dapat menurunkan kadar fosfor pada kisaran 84,272-62,806 ppm, dengan kadar total karotenoid sebesar 5831-6786 mg/kg dan total tokoferol yaitu 2081-2399 $\mathrm{mg} / \mathrm{kg}$. Proses degumming yang efektif untuk menurunkan kadar fosfor minyak buah merah kasar adalah pada perlakuan dengan konsentrasi asam sitrat $1 \%$.
\end{abstract}

Kata kunci: buah merah (Pandanus conoideus L.), degumming, asam sitrat, kualitas minyak. 


\section{PENDAHULUAN}

Buah merah (Pandanus conoideus L.) secara tradisional telah digunakan oleh masyarakat Papua dalam bentuk segar atau dalam bentuk olahan saos dan minyak (Roreng dan Nishigaki, 2013). Minyak buah merah juga dikenal memiliki khasiat terhadap kesehatan manusia, dan dilaporkan dapat mencegah serta mengobati berbagai penyakit seperti penyakit mata, penyakit kulit, penyakit jantung dan tuberkulosis (Budi dan Paimin, 2005), serta dapat menghambat sel kanker dan sel tumor (Mun'im dkk., 2006; Surono dkk., 2008). Khasiat minyak buah merah tersebut dimungkinkan karena kandungan komponen aktifnya yaitu senyawa antioksidan seperti karotenoid dan tokoferol (Sarungallo dkk., 2015; Murtiningrum dkk., 2019), serta asam lemak tidak jenuh seperti asam oleat, asam linoleat, dan asam linolenat yang merupakan asam lemak esensial (Sarungallo dkk., 2015; Murtiningrum dkk., 2019). Komponen aktif tersebut sangat mudah mengalami degradasi selama proses pengolahan terutama pada tahap ekstraksi dan pemurnian, sehingga mempengaruhi kualitas minyak yang dihasilkan (Sarungallo dkk., 2014).

Minyak buah merah dapat diperoleh dengan cara diekstrak dari daging buah. Cara ekstraksi yang umumnya dilakukan oleh masyarakat lokal Papua adalah dengan cara basah yaitu buah dipotong, dicuci bersih, dikukus atau direbus, lalu ditambahkan air kemudian dilumatkan sehingga menghasilkan pasta. Selanjutnya, pasta dimasak menggunakan panas dengan suhu yang cukup tinggi untuk menguapkan air sehingga lemak yang terkandung dapat dipisahkan (Limbongan dan Malik, 2009). Minyak hasil ekstraksi merupakan minyak kasar yang masih mengandung sejumlah komponen selain trigliserida yaitu gum (fosfolipid), karbohidrat, protein dan beberapa komponen lainnya yang tidak diinginkan di dalam minyak (Ketaren, 1986). Sarungallo dkk., (2015) melaporkan bahwa minyak buah merah hasil ekstraksi mengandung fosfor 38-374 ppm yang berperan sebagai emulsifier sehingga dapat mengikat komponen-komponen pengotor dalam minyak. Ditambahkan pula bahwa fosfor (sebagai fosfolipid) tidak diinginkan dalam minyak karena dapat menyebabkan masalah selama pemurnian khususnya degumming. Adanya fosfor akan bereaksi dengan logam dan asam lemak bebas yang dapat mengakibatkan kerusakan oksidasi. Adanya komponen pengotor tersebut juga dapat menyebabkan rasa lengket, rasa getir, memicu terjadinya reaksi hidrolisis yang dapat mengakibatkan ketengikan minyak, memperpendek umur simpan, serta menurunkan kualitas minyak (Anderson, 1996). Sehingga minyak buah merah perlu dimurnikan dahulu sebelum dikonsumsi.

Degumming merupakan salah satu tahapan proses pemurnian yang bertujuan untuk memisahkan getah dan lendir (fosfolipid, protein, residu dan karbohidrat) dalam minyak tanpa mengurangi jumlah asam lemak bebas (ALB) minyak. Prinsip kerja degumming adalah memisahkan senyawa fosfatida ke dalam fase air sehingga dapat dipisahkan dengan cara pengendapan, penyaringan atau, pemusingan/sentrifugasi (Ketaren, 1986). Proses degumming dapat dilakukan melalui beberapa cara yaitu degumming menggunakan natrium klorida (NaCl) (Jazuli dan Susila, 2013), asam sulfat (Qiqmana dan Sutjahjo, 2014), asam fosfat (Ristianingsih dkk., 2011), asam sitrat (Sarungallo dkk., 2011; Murtiningrum dkk., 2011), enzim (Aniq dkk., 2014), dan teknologi membran (Murtiningrum, 2004). Proses degumming menggunakan air dan asam juga lebih efektif memisahkan getah dan lendir dalam minyak karena asam dapat mengikat kotoran dalam minyak seperti logam yang berupa fosfatida. Sedangkan air melarutkan asam dan memisahkan kotoran-kotoran yang tidak larut dalam lemak. Disamping itu degumming menggunakan asam dan air umumnya lebih banyak digunakan dalam industri minyak goreng karena penggunaannya lebih ekonomis, aman untuk dikonsumsi dalam jumlah banyak dan mudah ditemukan (Anderson, 2005). Dilaporkan pula bahwa proses degumming minyak kasar buah merah menggunakan asam sitrat $0,2 \%$ dapat menurunkan kadar fosfor minyak buah merah yaitu dari 80 ppm menjadi 60 ppm (Murtiningrum dkk., 2011). Tujuan penelitian ini adalah untuk menentukan pengaruh proses degumming menggunakan asam sitrat terhadap kualitas minyak buah merah. 


\section{METODOLOGI}

\section{Bahan dan alat}

Bahan-bahan yang digunakan dalam penelitian ini terdiri atas (1) bahan baku utama yaitu minyak buah merah yang diperoleh dari UMKM HESTA di Kabupaten Manokwari, Provinsi Papua Barat sebanyak $500 \mathrm{ml}$ dengan cara ekstraksi basah; (2) bahan untuk degumming minyak buah merah yaitu asam sitrat dan aquades; (3) bahan kimia untuk analisis kualitas minyak buah merah (kadar air, ALB, bilangan peroksida, Kadar fosfor, total karoten, dan total tokoferol) yaitu alkohol netral 95\%, indikator fenolftalin 1\%, kalium hidroksida $(\mathrm{KOH}) 0,1 \mathrm{~N}$, larutan asam asetat glasial, kloroform, kalium iodida, natrium sulfat $0,1 \mathrm{~N}$, larutan pati, butylated hydroxytoluene (BHT) 0,1\%, heksan, etanol $95 \%$, amonium molibdat, amonium vanadat, larutan fosfat standar, asam nitrat pekat, dan asam sulfat pekat.

Peralatan yang digunakan untuk penelitian ini meliputi: (1) alat untuk degumming minyak buah merah yaitu tabung reaksi, hotplate, alat sentrifugasi, water bath, sudip, dan $\mathrm{pH}$ meter serta; (2) alat untuk analisis yaitu, gelas beker, tabung reaksi, pipet tetes dan pipet ukur, buret, labu ukur, gelas piala, spektrofotometer, vorteks, oven, timbangan dan analitik.

\section{Metode penelitian}

Penelitian ini menggunakan Rancangan Acak Lengkap (RAL) yang terdiri dari empat perlakuan, yaitu tanpa degumming, degumming menggunakan 3 konsentrasi asam sitrat yang meliputi $0,2 \%, 0,5 \%$ dan $1 \%$. Masing-masing perlakuan tersebut diulang sebanyak tiga kali.

Penelitian ini terdiri atas dua tahap penelitian yaitu: (1) Degumming minyak kasar buah merah dan; (2) analisis kualitas minyak buah merah hasil degumming. Pelaksanaan penelitian ditampilkan pada Gambar 1. Variabel pengamatan pada penelitian ini adalah rendemen, kadar air, asam lemak bebas (ALB), bilangan peroksida (BP), kadar fosfor, total karoten dan tokoferol minyak buah merah setelah degumming.

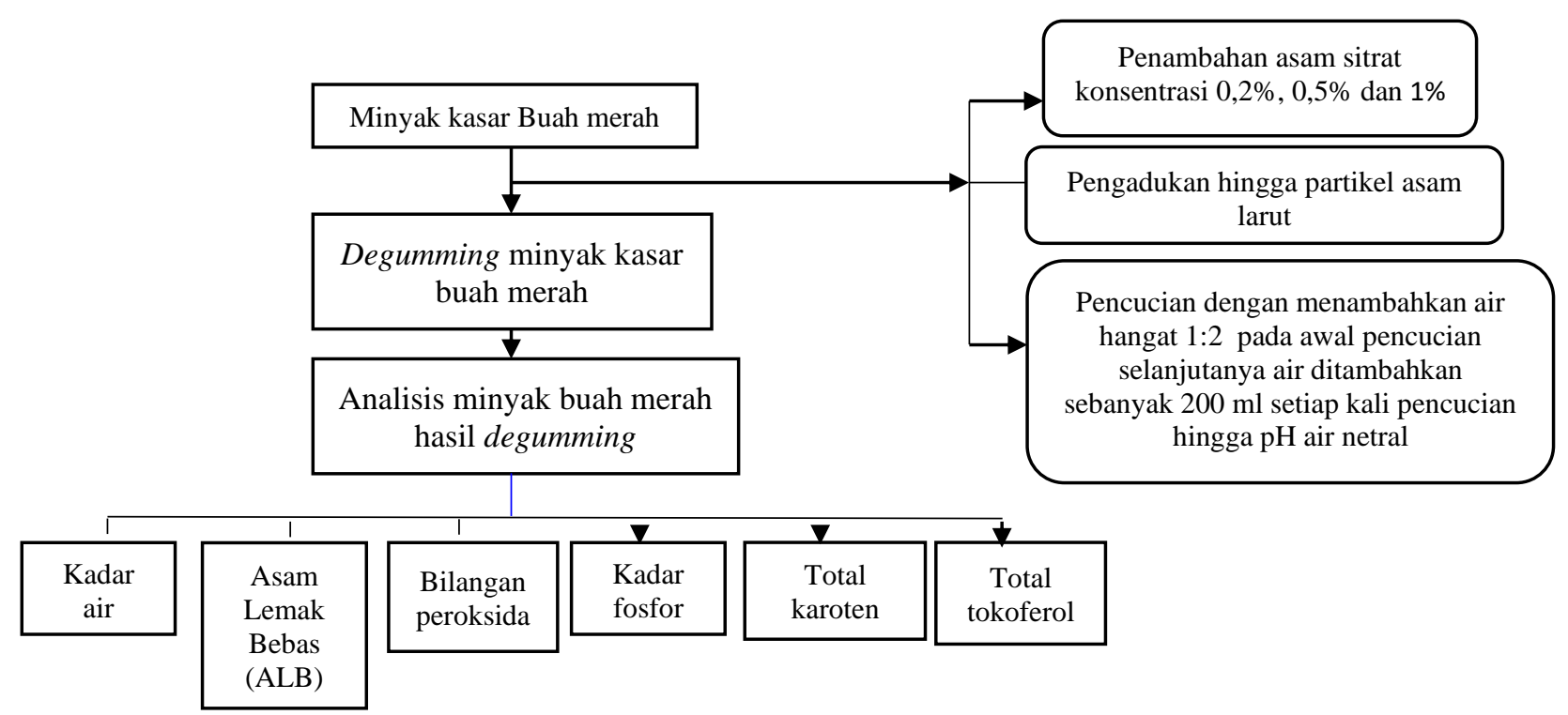

Gambar 1. Diagram Alir Pelaksanaan Penelitian

\section{Proses Degumming Minyak Kasar Buah Merah.}

Tahap ini dimaksudkan untuk menghilangkan getah dan lendir (fosfalipid, protein, residu dan karbohidrat) dalam minyak dimana adanya senyawa-senyawa tersebut mempengaruhi mutu minyak buah merah. Pada tahap ini dilakukan degumming menggunakan 3 konsentrasi asam sitrat yaitu konsentrasi $0,2 \%, 0,5 \%$, dan $1 \%$.

Proses ini dilakukan dengan cara minyak buah merah ditambahkan dengan asam 
sitrat dengan konsentrasi sesuai perlakuan, kemudian dipanaskan di dalam waterbath sambil diaduk selama 5 menit hingga partikel asam sitrat yang ditambahkan larut. Selanjutnya dilakukan proses pencucian minyak dengan cara menambahkan aquades hangat dengan perbandingan air dan minyak 2:1, lalu diaduk, dan disentrifugasi selama 5 menit, sehingga minyak akan terpisah dari gum dan air. Minyak buah merah yang terdapat pada bagian atas dapat dipisahkan dari gum dan air menggunakan pipet. Proses pencucian minyak dilakukan hingga $\mathrm{pH}$ air pencucian netral $(\mathrm{pH}=7)$.

\section{Analisis Kualitas Minyak Buah Merah Hasil Degumming}

Tahap ini ditujukan untuk mengetahui kualitas minyak buah merah hasil degumming, yang dibandingkan dengan minyak buah merah tanpa degumming. Kualitas kimia minyak buah merah yang diukur yaitu kadar air (AOAC, 2005), asam lemak bebas (ALB) (AOCS, 2003), bilangan peroksida (AOAC, 2005), fosfor (AOCS, 2003), total karoten (Knockaert dkk., 2012) dan total tokoferol (Wong dkk., 1988).

\section{Analisis Data}

Data yang diperoleh dari penelitian ini dianalisis secara statistik menggunakan analisis ragam dan jika berbeda nyata maka akan dilanjutkan dengan Analisis DMRT (Duncan's Multiple Range Test) menggunakan Program SPSS (Statistical Product and Service Solutions) seri 17.0.

\section{HASIL DAN PEMBAHASAN}

\section{Degumming Minyak Buah Merah}

Proses degumming merupakan suatu proses pemisahan getah atau lendir-lendir yang terdiri dari fosfatida, protein residu, karbohidrat, air dan resin (Ketaren, 1986). Dalam penelitian ini degumming dilakukan dengan cara asam yaitu dengan cara menambahkan asam sitrat dalam minyak kasar buah merah lalu dipanaskan hingga partikel asam sitrat yang dimasukkan larut sambil diaduk dalam waterbath, kemudian minyak tersebut dicuci menggunakan air hangat 2:1 pada pencucian pertama. Selanjutnya air ditambahkan sebanyak $200 \mathrm{ml}$ setiap kali pencucian hingga pH air menjadi netral. Tujuan penambahan asam sitrat adalah untuk mengubah fosfatida yang nonhydratable menjadi hydratable sehingga mudah dipisahkan dalam proses pencucian. Selanjutnya dilakukan proses sentrifugasi untuk mempercepat proses pemisahan minyak, gum dan air, yang hasilnya disajikan pada Gambar 2.

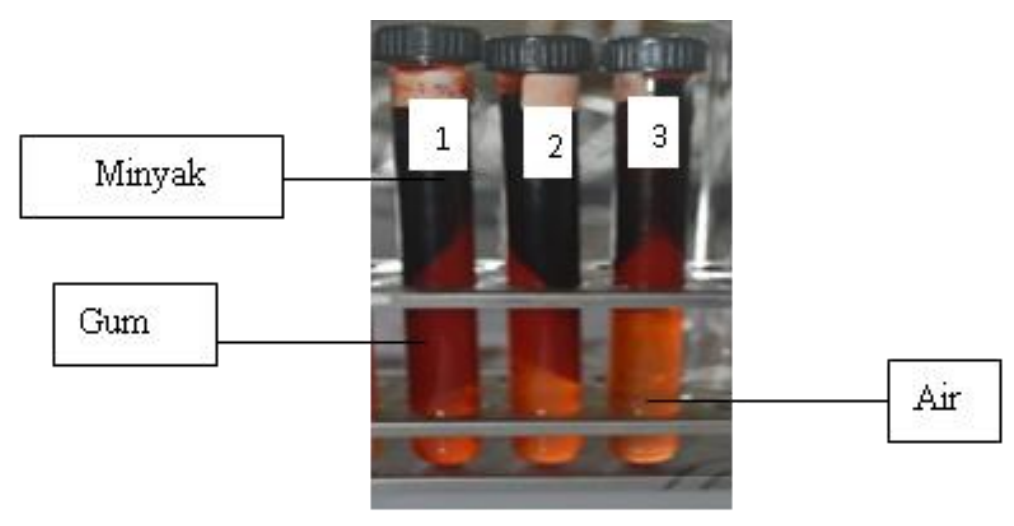

Gambar 2. Minyak buah merah degumming setelah tahap sentrifugasi.

Rendemen minyak yang dihasilkan setelah proses degumming ditampilkan pada Tabel 5. Hasil tersebut menunjukkan bahwa semakin tinggi konsentrasi asam sitrat yang digunakan maka semakin rendah rendemen minyak buah merah yang dihasilkan. Penurunan rendemen minyak disebabkan karena perpindahan massa minyak ke dalam fase asam sitrat yang diawali dengan massa gum yang terikat dalam minyak berikatan dengan lapisan antar fase minyak dan fase cairasam sitrat (Gambar 2). Semakin tinggi konsentrasi asam sitrat maka semakin banyak massa minyak yang terikat pada fase cair-asam sitrat. Dengan demikian semakin banyak massa minyak yang terikat pada gum dan ikut terbuang pada saat pencucian dan menurunkan rendemen minyak yang dihasilkan. 
Tabel 1. Rendemen minyak buah merah setelah degumming menggunakan beberapa konsentrasi asam sitrat.

\begin{tabular}{cc}
\hline $\begin{array}{c}\text { Konsentrasi asam } \\
\text { sitrat }\end{array}$ & $\begin{array}{c}\text { Rendemen minyak } \\
(\boldsymbol{\%})\end{array}$ \\
\hline $0,2 \%$ & 26,281 \\
$0,5 \%$ & 24,028 \\
$1 \%$ & 8,379 \\
\hline
\end{tabular}

\section{Kualitas Minyak Buah Merah Setelah Degumming. \\ Kualitas kimia minyak buah merah} setelah degumming, yang meliputi kadar air, ALB, Bilangan Peroksida, Fosfor, Total Karotenoid dan Tokoferol disajikan pada Tabel 2.

Tabel 2. Kualitas minyak buah merah setelah proses degumming.

\begin{tabular}{lcccc}
\hline \multirow{2}{*}{$\begin{array}{c}\text { Parameter kualitas } \\
\text { minyak buah merah }\end{array}$} & $\begin{array}{c}\text { Tanpa } \\
\text { degumming }\end{array}$ & $\begin{array}{c}\text { Konsentrasi } \\
\text { asam sitrat } \\
\mathbf{0 , 2 \%}\end{array}$ & $\begin{array}{c}\text { Konsentrasi } \\
\text { asam sitrat } \\
\mathbf{0 , 5 \%}\end{array}$ & $\begin{array}{c}\text { Konsenrasi } \\
\text { asam sitrat } \\
\mathbf{1 \%}\end{array}$ \\
\hline Kadar air $(\%)$ & $0,249 \mathrm{c}$ & $0,053 \mathrm{a}$ & $0,071 \mathrm{ab}$ & $0,094 \mathrm{~b}$ \\
\hline $\mathrm{ALB}(\%)$ & $1,043 \mathrm{a}$ & $1,095 \mathrm{a}$ & $1,025 \mathrm{a}$ & $1,090 \mathrm{a}$ \\
\hline $\begin{array}{l}\text { Bilangan Peroksida } \quad(\mathrm{mg} \\
\left.\mathrm{O}_{2} / 100 \mathrm{mg}\right)\end{array}$ & $0,361 \mathrm{ab}$ & $0,291 \mathrm{a}$ & $0,428 \mathrm{ab}$ & $0,592 \mathrm{~b}$ \\
\hline Fosfor $(\mathrm{ppm})$ & $94,085 \mathrm{~d}$ & $84,272 \mathrm{c}$ & $76,621 \mathrm{~b}$ & $62,806 \mathrm{a}$ \\
\hline Total karotenoid $(\mathrm{mg} / \mathrm{kg})$ & $7.653 \mathrm{~b}$ & $6.786 \mathrm{~b}$ & $6.518 \mathrm{ab}$ & $5.831 \mathrm{a}$ \\
\hline Total tokoferol $(\mathrm{mg} / \mathrm{kg})$ & $2.727 \mathrm{~b}$ & $2.399 \mathrm{ab}$ & $2.144 \mathrm{a}$ & $2.081 \mathrm{a}$ \\
\hline
\end{tabular}

*) Huruf yang sama pada baris yang sama menunjukan perbedaan tidak nyata.

\section{Kadar Air}

Kadar air merupakan parameter penting bagi kualitas minyak. Adanya air dalam minyak dapat mempercepat kerusakan minyak seperti terjadinya reaksi hidrolisis dalam minyak yang ditandai dengan adanya bau tengik pada minyak (Ketaren, 1986).

Kadar air minyak buah merah setelah degumming dalam penelitian ini berkisar antara 0,053-0,094\% (Tabel 2). Hasil uji lanjut Duncan pada tingkat kepercayaan $95 \%$ menunjukkan bahwa minyak dengan kadar air tertinggi adalah perlakuan tanpa degumming, berbeda nyata dengan semua perlakuan minyak yang di-degumming. Rendahnya kadar air minyak yang di-degumming dapat disebabkan karena penggunaan asam sitrat. Asam sitrat akan merubah sifat gum dari non hydratable menjadi hydratable, dengan mengkondisikan keasaman minyak ( $\mathrm{pH}$ rendah) karena zat akan lebih mudah mengikat air pada kondisi asam (jumlah $\mathrm{H}+$ banyak), sehingga dalam tahapan proses selanjutnya akan mudah terbawa dalam fase air (Torrey, 1983) dan dapat dipisahkan dengan sentrifugasi.

Kadar air minyak buah merah, baik perlakuan tanpa maupun dengan degumming, yang dihasilkan dalam penelitian ini lebih rendah dari standar yang ditetapkan SNI untuk minyak makan. Kadar air maksimal yang ijinkan yaitu $0,1-0,15 \%$ untuk minyak goreng (SNI, 2014), 0,5\% pada minyak kelapa (SNI, 1992) dan minyak jagung sebagai minyak makan yaitu 0,20\% (SNI, 1998).

\section{Asam Lemak Bebas (ALB)}

Pada dasarnya minyak dan lemak tidak mengandung asam lemak bebas (ALB), tetapi dapat terbentuk oleh adanya enzim lipase dan air yang dapat menghidrolisis trigliserida dalam bahan pangan (Ketaren, 1986). Berdasarkan data pada Tabel 2, ALB minyak buah merah yang dihasilkan dengan dan tanpa proses degumming berkisar 1,025-1,095\%. Tampak pula bahwa ke-tiga konsentrasi asam sitrat yang digunakan dalam proses degumming memeiliki ALB yang tidak berbeda nyata dengan minyak tanpa didegumming. Hal ini dimungkinkan karena degumming dimaksudkan untuk memisahkan gum-gum atau lendir-lendir yang terdapat dalam minyak tetapi tidak mengurangi jumlah asam lemak bebas (Ketaren, 1986). Hal yang sama dilaporkan Sarungallodkk., (2009) bahwa degumming minyak buah merah kasar menggunakan asam sitrat $0,2 \%$, tidak 
menurunkan kadar ALBnya. Sedangkan Weidkk., (2004) melaporkan bahwa proses degumming dengan asam fofat dan bleaching menggunakan acid-activated clays cenderung meningkatkan ALB minyak sawit. Ditambahkan pula bahwa kadar ALB minyak buah merah hasil degumming menggunakan asam sitrat $2 \%$, juga meningkat yang diduga akibat terjadinya reaksi hidrolisis lemak, terutama selama tahap pencucian (Sarungallo dkk, 2018).

Kadar ALB maksimal untuk minyak goreng 0,3\% (SNI, 2014), minyak kelapa $0,5 \%$ (SNI, 1992), dan minyak jagung sebagai minyak makan maksimal 0,20\% (SNI, 1988). Oleh karena itu kadar ALB minyak buah merah yang dihasilkan dalam penelitian ini belum memenuhi standar yang ditetapkan.

\section{Bilangan Peroksida}

Bilangan peroksida adalah nilai terpenting untuk menentukan derajat kerusakan pada minyak atau lemak. Dalam waktu yang cukup lama peroksida dapat mengakibatkan dekstruksi beberapa macam vitamin dalam bahan pangan berlemak. Peroksida juga dapat mempercepat proses timbulnya bau tengik dan flavor yang tidak dikehendaki dalam bahan pangan. Jika jumlah peroksida dalam bahan pangan lebih besar dari 100 akan bersifat sangat beracun dan tidak dapat dimakan (Ketaren, 1986).

Data pada Tabel 2, menunjukan bahwa bilangan peroksida minyak buah merah setelah degumming yang dihasilkan dalam penelitian ini berkisar antara 0,291-0,592 $\mathrm{mg} \mathrm{O} / 100 \mathrm{mg}$. Hasil uji lanjutan dengan tingkat kepercayaan 95\% menunjukkan bahwa minyak buah merah yang didegumming tidak berbeda nyata dengan minyak buah merah tanpa degumming. Hal ini mengindikasikan bahwa proses degumming yang diaplikasikan dalam penelitian ini tidak memicu terjadinya reaksi oksidasi. Standar mutu bilangan peroksida maksimal untuk minyak goreng $10 \mathrm{mg} \mathrm{O} / 100 \mathrm{mg}$ (SNI, 2014), minyak kelapa 5,0 mg O2/100mg (SNI, 1992), dan pada minyak jagung sebagai minyak makan adalah $10 \mathrm{mg} \mathrm{O2/100mg} \mathrm{(SNI,} \mathrm{1992).}$ Dengan demikina bilangan peroksida yang terdapat dalam minyak buah merah hasil degumming yang dihasilkan aman untuk dikonsumsi.

\section{Kadar Fosfor}

Salah satu kotoran yang berbentuk suspensi koloid dalam minyak adalah fosfatida dan gum (Ketaren, 1986). Adanya kotoran seperti fosfolipid dan gum dalam minyak dapat memicu terjadinya reaksi hidrolisis dan oksidasi pada lemak minyak. Reaksi tersebut mengakibatkan lemak minyak menjadi mudah tengik sehingga kerusakan pada minyak lebih cepat terjadi. Selain itu, adanya komponen tersebut memperpendek umur simpan dan menurunkan kualitas lemak minyak (Anderson, 2005).

Kadar fosfor minyak buah merah yang dihasilkan dalam penelitian ini berkisar antara 62-94 ppm (Tabel 2). Hasil uji lanjutan menggunakan Uji Duncan pada tingkat kepercayaan 95\%, yang menunjukkan bahwa konsentrasi asam sitrat dapat menurunkan kadar fosfor secara nyata. Hal ini dapat dimungkinkan karena penggunaan larutan asam akan mengkelat $\mathrm{Ca}, \mathrm{Mg}$ dan $\mathrm{P}$ dalam minyak sehingga fosfolipid nonhydratable dikonversi menjadi hydratable, kemudian gum hydratable dipisahkan melalui sentrifugasi (Anderson 2005).

Proses degumming menggunakan asam sitrat pada konsentrasi 0,2\% dapat menurunkan kadar fosfor minyak buah merah sebanyak $10 \%$, pada konsentrasi asam sitrat $0,5 \%$ menurunkan sebanyak $18 \%$, dan pada konsentrasi asam sitrat $1 \%$ sebanyak $33 \%$. Murtiningrum dkk., (2011) melaporkan penggunaan asam sitrat dalam proses degumming dapat menurunkan kadar fosfor dari $80 \mathrm{ppm}$ menjadi $60 \mathrm{ppm}$ atau sebesar $25 \%$.

\section{Total Karoten}

Zat warna alami minyak buah merah (pigmen) yang berwarna kuning, orange hingga warna merah ini disebabkan oleh karotenoid (Ketaren, 1998). Karotenoid yang umumnya dikenal sebagai sumber vitamin $\mathrm{A}$ adalah $\alpha$ - karoten, $\beta$ - karoten dan $\gamma$ - karoten (Petterson, 1992). Minyak buah merah yang didegumming berdasarkan hasil penelitian ini memiliki total karoten berkisar antara 5.831$6.786 \mathrm{mg} / \mathrm{kg}$. Hasil analisis sidik ragam menunjukkan bahwa ke-tiga konsentrasi asam yang digunakan dalam proses degumming berpengaruh nyata terhadap total karotenoid minyak buah merah yang dihasilkan. Hasil uji lanjut Duncan pada tingkat kepercayaan 95\% menunjukkan bahwa penggunaan konsentrasi 
asam sitrat $0,2 \%$ dan $0,5 \%$ tidak berpengaruh terhadap minyak buah merah tanpa degumming.

Data pada Tabel 2, menunjukan bahwa total karoten minyak buah merah yang dihasilkan cenderung menurun dengan meningkatnya konsentrasi asam sitrat. Ketaren, (1986) menyatakan bahwa karotenoid merupakan hidrokarbon dan zat warna alami yang mudah teroksidasi oleh atmosfer. Wilskajeska, (2002), menambahkan pula bahwa karoten dan tokoferol mudah terpengaruh terhadap oksigen, cahaya, suhu, dan keasaman karena memiliki struktur dan ikatan rangkap yang terkonyugasi yang mengandung banyak elektron reaktif dan mudah teroksidasi. Oleh karena itu penggunaan asam dan proses pencucian diduga berkontribusi dalam menurunkan kadar total karoten minyak buah merah yang dihasilkan.

\section{Total Tokoferol}

Tokoferol adalah senyawa kelas kimia yang banyak memiliki aktivitas vitamin $\mathrm{E}$. Tokoferol larut dalam lemak dan dikenal sebagai antioksidan yang memiliki banyak fungsi bagi kesehatan manusia (Winarsi, 2007). Kandungan tokoferol minyak buah merah yang dihasilkan dalam penelitian ini berkisar antara 2.081-2.727 mg/kg (Tabel 2).

Hasil analisis sidik ragam menunjukkan dari ke-tiga konsentrasi yang digunakan dalam proses degumming berpengaruh nyata terhadap total tokoferol minyak buah merah yang dihasilkan. Hasil uji lanjut Duncan pada tingkat kepercayaan 95\% menunjukan bahwa penggunaan konsentrasi asam sitrat $0,2 \%$ tidak berbeda nyata dengan perlakuan tanpa degumming, namun berbeda nyata pada penggunaan konsentrasi asam sitrat $1 \%$. Sedangkan penggunaan konsentrasi asam sitrat $0,5 \%$ dan $1 \%$ berbeda nyata terhadap minyak buah merah tanpa degumming.

Data Tabel 2, menunjukkan bahwa total tokoferol minyak buah merah semakin menurun seiring meningkatnya konsentrasi asam sitrat. Sama halnya dengan karotenoid minyak buah merah yang dihasilkan dalam penelitian ini bahwa menurunnya total tokoferol dapat dikontribusi oleh penggunaan asam dan proses pencucian. Tokoferol merupakan senyawa yang sangat sensitif (Wilka-Jeska, 2002; Ketaren, 1986), sehingga mudah terdegradasi oleh asam dan proses pencucian yang diaplikasikan dalam proses degumming minyak buah merah.

\section{KESIMPULAN}

Proses degumming menggunakan asam sitrat pada konsentrasi 0,2-1\% menghasilkan minyak buah merah dengan kadar air (0,053-0,094\%), asam lemak bebas (ALB) (1,025-1,095\%), bilangan peroksida (0,291-0,592 $\left.\mathrm{mg} \mathrm{O}_{2} / 100 \mathrm{mg}\right)$, dan dapat menurunkan kadar fosfor pada kisaran 84,272-62,806 ppm, dengan kadar total karotenoid sebesar 5831-6786 mg/kg dan total tokoferol yaitu $2081-2399 \mathrm{mg} / \mathrm{kg}$. Proses degumming minyak buah merah yang efekif menurunkan kadar fosfor menggunakan asam sitrat $1 \%$ namun memiliki kadar rendemen terendah dan penurunan kadar karotenoid dan tokoferol terbesar.

\section{UCAPAN TERIMA KASIH}

Peneliti mengucapkan terima kasih kepada Kementerian Riset dan Teknologi Pendidikan Tinggi - Republik Indonesia, atas bantuan dana penelitian yang diberikan melalui Hibah Penelitian Strategis Nasional tahun 2014.

\section{DAFTAR PUSTAKA}

Anderson, D., (2005), A Primer on Oils Processing Technology, dalam: F. Shahidi (Ed.). Oil and Fat Products: Processing Technologies. Bailey's Industrial Oil and Fat Products. Sixth Edition Volume 5 Edible John Wiley \& Sons, Inc., Publication. New Jersey.

Aniq, N., Aqil, H., Yatun, I. dan Hartati, I., (2014), Biodegumming rami menggunakan enzim amobil dari cairan rumen sapi. Fakulas Teknik, Universitas Wahid Hasyim. Semarang.

AOAC (Association of Analytical Chemist' Society), (2003), Official Metods of Analysis of the AOAC. $5^{\text {th }} \mathrm{Ed}$. AOAC, Champaign, Illinois

AOCS (American Oil Chemists' Society), (2003), Official Methods and Recommended Practices of the AOCS. 5 th ${ }^{\text {ed }}$. AOCS. Champaign, Illinois. 
Budi, I. M., dan Paimin, F.R., (2005), Buah Merah. Penebar Swadaya. Jakarta.

Jazuli, A., dan Susila, I. W., (2013), Perbaikan kualitas minyak biji karet (CRSO) melalui proses degumming menggunakan natrium klorida $(\mathrm{NaCl})$ sebagai bahan baku pembuatan biodisel. Jurnal Teknik Mesin, 2(1), pp. 25-30.

Ketaren, S., (1986), Minyak dan Lemak Pangan. Penerbit Universitas Indonesia, Jakarta.

Knockaert, G., Lemmens, L., VanBuggenhout, S., Hendrickx, M., and Van-Loey, A., (2012), Changes in $\beta$ carotene bioaccessibility and concentration during processing of carrot puree. Food chemistry, 133 (1), pp. 60-67.

Limbongan, J., dan Malik, A., (2009), Peluang Pengembangan Buah Merah (Pandanus conoideus Lamk.) di Provinsi Papua. Jurnal Litbang Pertanian, 28(4), pp. 134-136.

Mun'im, A., Andrajati, R. dan Susilowati, H., (2006), Uji Hambatan Tumorigenesis Sari Buah Merah (Pandanus Conoideus Lamk.) terhadap Tikus Putih Betina yang diinduksi 7,12 Dimetilbenz (A) Antrasen (DMBA). Majalah Ilmu Kefarmasian, 3(3), pp. 153-161.

Murtiningrum, (2004), Ekstraksi Minyak Dengan Metode Wet Rendering dari Buah Pandan (Pandanus conoideus L) dan Pemurnian dengan Filtrasi Membran. (Tesis). Institut Pertanian Bogor, Bogor.

Murtiningrum, Sarungallo, Z.L. dan Roreng, M.K., (2011), Kandungan Komponen Aktif Minyak Kasar Dan Hasil Degumming Dari Buah Merah (Pandanus conoideus) yang Diekstrak Secara Tradisional. Prosiding Seminar Nasional Perhimpunan Ahli Pangan Indonesia (PATPI). Manado, Sulawesi Utara, Indonesia. pp. 157-160.

Petterson, H.B.W, (1992), Bleaching and Purifying Fats and Oils. American Oil Chemist's Society, USA.

Qiqmana, A.M. dan Sutjahjo, D.H., (2014), Karakteristik Biodisel dari Minyak Nyamplung dengan Proses Degumming menggunakan Asam Sulfat dan Asam Cuka. Fakultas
Teknik. Jurusan Teknik Mesin. Universitas Negeri Surabaya. Jurnal Teknik Mesin. 2(3), pp. 132-139.

Ristianingsih, Y., Sutijan dan Budiman, A., (2011), Studi Kenetika Proses Kimia Dan Fisika Penghilangan Getah Crude Palm Oil (CPO) dengan Asam Fosfat. Proses Sistem Engginering Research Group, Jurusan Teknik Kimia, Fakultas Teknik, Universitas Gajah Mada. Reaktor, 13(4), pp. 242-247.

Roreng, M. K., dan Nishigaki, T., (2013), Buah Merah and Papuan People. Warta Industri Hasil Pertanian, 30(1), pp. 37-48.

Sarungallo, Z. L., Hariyadi, P., Andarwulan, N., and Purnomo, E. H., (2015), Characterization of chemical properties, lipid profile, total phenol and tocopherol content of oils extracted from nine clones of red fruit (Pandanus conoideus). Kasetsart Journal (Nature Science), 49(1), pp. 237-250.

Sarungallo, Z. L., Hariyadi, P., Andarwulan, N., dan Purnomo, E. H., (2014), Pengaruh Metode Ekstraksi Terhadap Mutu Kimia dan Komposisi Asam Lemak Minyak Buah Merah (Pandanus conoideus). Jurnal Teknologi Industri Pertanian, 24(3), pp. 209-217.

Sarungallo, Z. L., Santoso, B., Lisangan, M. M., Paiki, S. N. P., Situngkir, R. U., dan Asokawati, E., (2018), Kinetika Perubahan Mutu Minyak Buah Merah (Pandanus conoideus) Hasil Degumming Selama Penyimpanan. Jurnal Aplikasi Teknologi Pangan, 7 (4), pp. 156-162.

Sarungallo, Z.L., Murtiningrum, Paiki, S.N.P., (2009), Sifat Fisikokimia Minyak Kasar dan Hasil Degumming dari Buah Merah (Pandanus conoideus L.) yang diekstrak secara tradisional Merdey. Jurnal Agrotek, 1(6), pp. 9-15.

Standar Nasional Indonesia (SNI)-3741, (2014), Minyak Goreng Sawit. Badan Standarisasi Nasional (BSN). Jakarta.

Standar Nasional Indonesia (SNI) 01-2901, (2006), Minyak Kelapa Sawit Mentah (Crude Palm Oil). Badan Standarisasi Nasional (BSN). Jakarta.

Standar Nasional Indonesia (SNI) 01-3394, (1998). Minyak Jagung Sebagai 
Minyak Makan. Badan Standarisasi Nasional (BSN). Jakarta.

Standar Nasional Indonesia (SNI) 7381, (2008), Minyak Kelapa Virgin (VCO). Badan Standar Nasional (BSN). Jakarta.

Standar Nasional Indonesia (SNI)., (1992), Mutu dan Cara Uji Minyak Kelapa. Badan Standarisasi Nasional (BSN). Jakarta.

Surono I., Endaryanti, T.A. dan Nishigaki, T., (2008), Indonesian Biodiversities, From Microbes To Herbal Plants As Potential Funcional Foods. Journal of The Faculty of Agricullture Shinsu University. 44 (1.2), pp. 23-27.

Torrey, S., (1983), Edible Oil and Fats. Noyes Data Corporation, New Jersey, USA.

Wei, P.C., May, C.Y., Ngan, M. A., and Hock, C.C., (2004), Degumming and bleaching: effect on selected constituents of palm oil. Journal of Oil Palm Research, 16 (2), pp. 57-63.

Wilska-Jeska, J., (2002), Food Coloransts. Dalam: Sikorski ZE, Editor. Chemichal And Functional Properties Of Food Componensts. Second Edition. CRC Press. New York.

Winarsi, H., (2007), Antioksidan Alami dan Radikal Bebas, Potensi dan Aplikasinya dalam Kesehatam. Penerbit kanisius (Anggota IKAPI). Yogyakarta. Indonesia.

Wong, M.L., Timms, R.E and Goh, E.M., (1988), Colorimetric determination of total tocopherols in palm olein and stearin. Journal of the American Oil Chemists' Society, 65, pp. 258-261. 